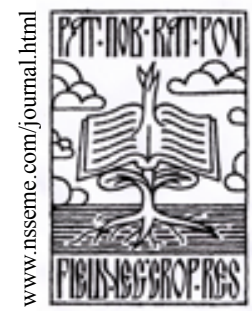

\title{
Molecular Evaluation of Genetic Variability in Tomato (Lycopersicon esculentum Mill.) Genotypes by Microsatellite Markers
}

\author{
Svetlana Glogovac • Adam Takač • Ljiljana Brbaklić • Dragana Trkulja • \\ Janko Červenski • Jelica Gvozdanović Varga • Vukašin Popović
}

\author{
received: 22 August 2013, accepted: 2 October 2013 \\ published online: 10 December 2013 \\ (c) 2013 IFVC \\ doi: $10.5937 /$ ratpov50-4344
}

\begin{abstract}
Summary: The objective of this research was to assess genetic diversity using eight microsatellite markers in 30 tomato genotypes from the collection of the Institute of Field and Vegetable Crops in Novi Sad. The SSR markers were selected from publicly available data and Solanaceae Genome Network database. Genotypes were grouped into three clusters, using Ward's hierarchical clustering method and Euclidean distance measure. Markers SSR248, TMS9, TMS42 and SSR111 had very high PIC (Polymorphism information content) values and can be recommended for the future studies.
\end{abstract}

Key words: genetic variability, genetics, Lycopersicon esculentum, microsatellites, SSR markers, tomatoes

\section{Introduction}

Harvested areas, quantity production and human consumption provided an important place for tomato (Lycopersicon esculentum Mill.) among other vegetable plants. According to FAO statistical data (Food and Agriculture Organization of the United Nations 2011), the global harvested area of tomato was 4,751,530 ha in 2011. Although derived from highly variable natural habitat, a huge part of genetic variability was lost due to inbreeding during tomato domestication and intensive artificial selection. A huge number of tomato varieties and hybrids were developed by tomato breeders with the aim to overcome existing genotypes in terms of yield, resistance to biotic and abiotic stress and fruit quality. Access to divergent breeding material is necessary for achieving these objectives. Despite the highly diverse natural habitat of the genus Lycopersicon that resulted in great variability of its species, cultivated tomato has a very narrow genetic base. Assessment of genetic diversity in any crop species provides a basis for

S. Glogovac* • A. Takač • Lj. Brbaklić • D. Trkulja • J. Červenski • J. Grozdanović-Varga • V. Popović

Institute of Field and Vegetable Crops, 30 Maksima Gorkog, 21000

Novi Sad, Serbia

e-mail: svetlana.glogovac@nsseme.com devising future strategies for crop improvement, conservation and sustainable use (Yi et al. 2008). Molecular markers represent useful tool in these types of studies. Simple sequence repeats (SSRs), also known as microsatellites, have very important role in molecular research having high reproducibility, multi-allelic nature, co-dominant inheritance, high abundance and wide genome coverage (El-Awady et al. 2012). Microsatellites are widely used in studies in different plant species (Stich et al. 2006, Cadalen et al. 2010, Brbaklić et al. 2010, Trkulja et al. 2011, Shah et al. 2013). Numerous studies have pointed to the efficacy of SSR markers for determination of genetic diversity in the genus Solanum (Alvarez et al. 2001, He, Poysa, \& Yu 2003, Frary et al. 2005, Garcia-Martinez et al. 2006, Hu et al. 2012). As a consequence of current breeding strategies, diverse local populations and old cultivars are suppressed by modern, high yielding cultivars, uniform with a narrow allelic variability at agronomically important loci. Since the loss of specific alleles means loss of opportunities to develop new and improve existing varieties and

\section{Acknowledgements:}

This research was supported by the Ministry of Education, Science and Technological Development of the Republic of Serbia as a part of the Project TR 31030 
hybrids, the aim of this research was to evaluate genetic variability of 30 tomato genotypes using eight SSR markers.

\section{Materials and Methods}

Thirty genotypes from tomato collection of the Institute of Field and Vegetable Crops (Novi Sad, Serbia) were chosen in order to assess genetic diversity using eight SSR markers (Tab. 1). Plant material originating from different parts of the world included 4 wild Lycopersicon species, 4 local populations, 16 old cultivars, 5 commercial cultivars and 1 breeding line. From the Sol Genomics Network (SGN; available at http://solgenomics.net/), after Bombarely et al. (2011) and publicly available data (Frary et al. 2005, Chen et al. 2009) the following microsatellite markers were selected: SSR248, SSR111, SSR9, SSR66, SSR304, SSR80, TMS9 and TMS42 (Tab. 2). The seedlings were grown in wooden boxes in greenhouse for two weeks. Genomic DNA was extracted from leaf tissue using modified CTAB isolation method (Doyle

Table 1. Analyzed tomato genotypes from the collection of the Institute of Field and Vegetable Crops, Novi Sad

\begin{tabular}{|c|c|c|c|}
\hline $\begin{array}{c}\text { Collection } \\
\text { number }\end{array}$ & $\begin{array}{c}\text { Common } \\
\text { genotype name }\end{array}$ & Origin & $\begin{array}{c}\text { Type } \\
\text { of material }\end{array}$ \\
\hline S 3 & Alice Roosevelt & USA & old cultivar \\
\hline S 15 & Novosadski niski & Serbia & commercial cultivar \\
\hline S 30 & Idyll & Germany & old cultivar \\
\hline S 42 & Kurtovski & Bulgaria & old cultivar \\
\hline S 46 & Bačka & Serbia & commercial cultivar \\
\hline S 50 & Knjaz & Serbia & commercial cultivar \\
\hline S 70 & Skopski rani & FYROM & local population \\
\hline S 99 & Novosadski rani & Serbia & local population \\
\hline S 100 & Novosadski export & Serbia & local population \\
\hline S 112 & Cverglan & Hungary & local population \\
\hline S 119 & Licopersicon peruvianum & South America & wild species \\
\hline S 120 & Licopersicon pimpinelliofolium & South America & wild species \\
\hline S 122 & Pegaz & Serbia & commercial cultivar \\
\hline S 200 & Acumare le caste & Italy & old cultivar \\
\hline S 212 a & Micado wioleto & Italy & old cultivar \\
\hline S 214 & Lycopersicon birsutum $f$. glabratum & $\begin{array}{l}\text { Western parts of South America } \\
\text { (Galapagos) }\end{array}$ & wild species \\
\hline S 218 & Lycopersicon esculentum var. cerasiforme & Western parts of South America & wild species \\
\hline S 319 & Gloria di Milano & Italy & old cultivar \\
\hline S 320 & Sunny Brok & USA & old cultivar \\
\hline S 332 & Antimold B & USA & old cultivar \\
\hline S 336 & San Marzano & Italy & old cultivar \\
\hline S 370 & Lampadina 7 & Italy & old cultivar \\
\hline S 399 & VF 145-21-4 & Denmark & breeding line \\
\hline S 427 & Hode & Netherlands & old cultivar \\
\hline S 477 & Indiana & USA & old cultivar \\
\hline S 534 & NR 189 & Denmark & old cultivar \\
\hline S 545 & Benarys Gartenfreude & Germany & old cultivar \\
\hline S 563 & Florida MH-1 & USA & old cultivar \\
\hline S 564 & Ontario red & Canada & old cultivar \\
\hline S 579 & Narvik SPF & Serbia & commercial cultivar \\
\hline
\end{tabular}


\& Doyle 1990). PCR amplifications were carried out in $10 \mu \mathrm{l}$ reaction volume: $30 \mathrm{ng}$ genomic DNA, $1 \times$ buffer, $2 \mathrm{mM} \mathrm{MgCl}_{2}, 0.2 \mathrm{mM}$ of dNTPs, 1 unit of Taq polymerase and $10 \mathrm{pmol}$ of reverse and forward primers. PCR products were separated by capillary electrophoresis using the ABI genetic analyzer Prism 3130 (Applied Biosystems, 850 Lincoln Centre Drive, Foster City, California 94404, USA). The amplification products were analyzed by GeneMapper Software Version 4.0. Polymorphism information content (PIC) was calculated according to Anderson, Churchill, Autrque, Tanksley, \& Sorrells (1993):

$$
\mathrm{PIC}=1-\underset{i=1}{k} p i^{2}
$$

where $p i$ is the frequency of the $i$-th allele out of the total number of alleles at an SSR locus, in the set of thirty tomato genotypes, and $k$ is a total number of different alleles of a given locus.

Statistical software Statistica 9 (StatSoft Inc. Corporation, Tulsa, USA) was used for genotype clustering using Ward`s hierarchical clustering method and Euclidean distance measure $\left(d_{\mathrm{E}}\right)$.

\section{Results and Discussion}

The genotypes were scored for the presence or the absence of the different SSR alleles. Eight loci were detected having total of 31 alleles, resulting in an average allele number of 3.9 per locus. Number of alleles per locus ranged from 3 to 5, while PIC values of selected markers varied from 0.12 (SSR9) to 0.73 (SSR248). Markers SSR248, TMS9, TMS42 and SSR111 were highly informative having PIC values over 0.5. Kwon, Parkl, \& Yi (2009) also found a high level of polymorphism for markers SSR248 and SSR111 with PIC values 0.75 and 0.88 , respectively. High PIC value for marker TMS9 (0.62) and low value for marker TMS42 (0.23) were reported by $\mathrm{He}$ et al. (2003). Genotypes were grouped into three clusters, but it was not possible to distinguish among genotypes with different origins (Fig. 1). The first group consisted of 10 genotypes and included 5 old cultivars, 2 wild species, 2 local populations and 1 commercial cultivar. In this group, no difference was revealed between cultivar S122 from Serbia and old cultivar S319 from Italy. The most distinct genotypes in this group were old cultivar S3 from the USA and old cultivar

Table 2. SSR markers used for molecular evaluation of 30 tomato genotypes

\begin{tabular}{|c|c|c|c|c|c|}
\hline Marker & $\begin{array}{l}\text { Chromo- } \\
\text { some }\end{array}$ & $\begin{array}{l}\text { Repeat } \\
\text { motif }\end{array}$ & Primer sequence (5'-3') & $\begin{array}{l}\text { No. } \\
\text { alleles }\end{array}$ & PIC \\
\hline SSR 248 & 10 & (ta) 21 & $\begin{array}{l}\text { f: GCATTCGCTGTAGCTCGTTT } \\
\text { r: GGGAGCTTCATCATAGTAACG }\end{array}$ & 5 & 0.73 \\
\hline SSR 111 & 3 & $\begin{array}{l}(\mathrm{tc}) 6 \\
(\mathrm{tctg}) 6\end{array}$ & $\begin{array}{l}\text { f: TTCTTCССTTCCATCAGTTCT } \\
\text { r: TTTGCTGCTATACTGCTGACA }\end{array}$ & 4 & 0.60 \\
\hline SSR 9 & 1 & (ata) 10 & $\begin{array}{l}\text { f: CCCTTTGCAAGTTCTTCTTCA } \\
\text { r: TTCATGAGCCAACATAGGAGG }\end{array}$ & 3 & 0.12 \\
\hline SSR 66 & 2 & (ata) 8 & $\begin{array}{l}\text { f: TGCAACAACTGGATAGGTCG } \\
\text { r: TGGATGAAACGGATGTTGAA }\end{array}$ & 3 & 0.24 \\
\hline SSR 304 & 7 & $(\mathrm{cca}) 7$ & $\begin{array}{l}\text { f: TCCTCCGGTTGTTACTCCAC } \\
\text { r: TTAGCACTTCCACCGATTCC }\end{array}$ & 3 & 0.24 \\
\hline SSR 80 & 11 & $\begin{array}{c}(\text { tttcaa }) 2 \\
(\text { gtacaa }) 2 \\
(\text { caa }) 7\end{array}$ & $\begin{array}{l}\text { f: GGCAAATGTCAAAGGATTGG } \\
\text { r: AGGGTCATGTTCTTGATTGTCA }\end{array}$ & 4 & 0.39 \\
\hline TMS 9 & 12 & (gata)26 & $\begin{array}{l}\text { f: TTGGTAATTTATGTTCGGGA } \\
\text { r: TTGAGCCAATTGATTAATAAGTTT }\end{array}$ & 4 & 0.70 \\
\hline TMS 42 & 11 & $\begin{array}{l}\text { (at) } 17 \\
(\mathrm{gt}) 18\end{array}$ & $\begin{array}{l}\text { f: AGAATTTTTTCATGAAATTGTCC } \\
\text { r: TATTGCGTTCCACTCCCTCT }\end{array}$ & 5 & 0.56 \\
\hline
\end{tabular}


S564 originating from Canada. Genotypes of the second group included 2 wild species, 1 cultivar in production and 1 old cultivar. The lowest $d_{\mathrm{E}}$ was obtained between cultivar S46 from Serbia and old cultivar S534 originating from Denmark. Wild species Lycopersicon birsutum $f$. glabratum (S214), originating from the western parts of South America (Galapagos), had the highest $d_{\mathrm{E}}$ from the rest of the second group genotypes, and from the majority of analysed genotypes. The third group, with 14 genotypes, contained 8 old cultivars, 3 commercial cultivars, 2 local populations and 1 breeding line. The lowest $d_{\mathrm{E}}$, in this group was determined between the following genotypes: two Italian, old cultivars, S336 and S370; cultivar S15 (Serbia) and old cultivar S320 (USA); old cultivar S563 (USA) and commercial cultivar S579 (Serbia). Two old cultivars, S336 and $\mathrm{S} 370$, except the same origin, have the same elongated „San Marzano“ fruit type. Obtained similarity between other genotypes could be the consequence of the small number of loci being used at this stage of study.
No difference was revealed between two old cultivars originating from Germany (S545 and S30), which were grouped separately from the rest of the analysed genotypes.

\section{Conclusions}

Four SSR markers (SSR248, TMS9, TMS42 and SSR111) had very high PIC values and can be recommended for the future studies. Most of the analysed genotypes could be distinguished using eight chosen SSR markers. For better germplasm characterization and development of potential markers for agronomically important traits, more SSR markers should be included in the analysis. This type of research, coupled with the results of field observations, can present a starting point for MAS (Marker Assisted Selection) in tomato breeding.

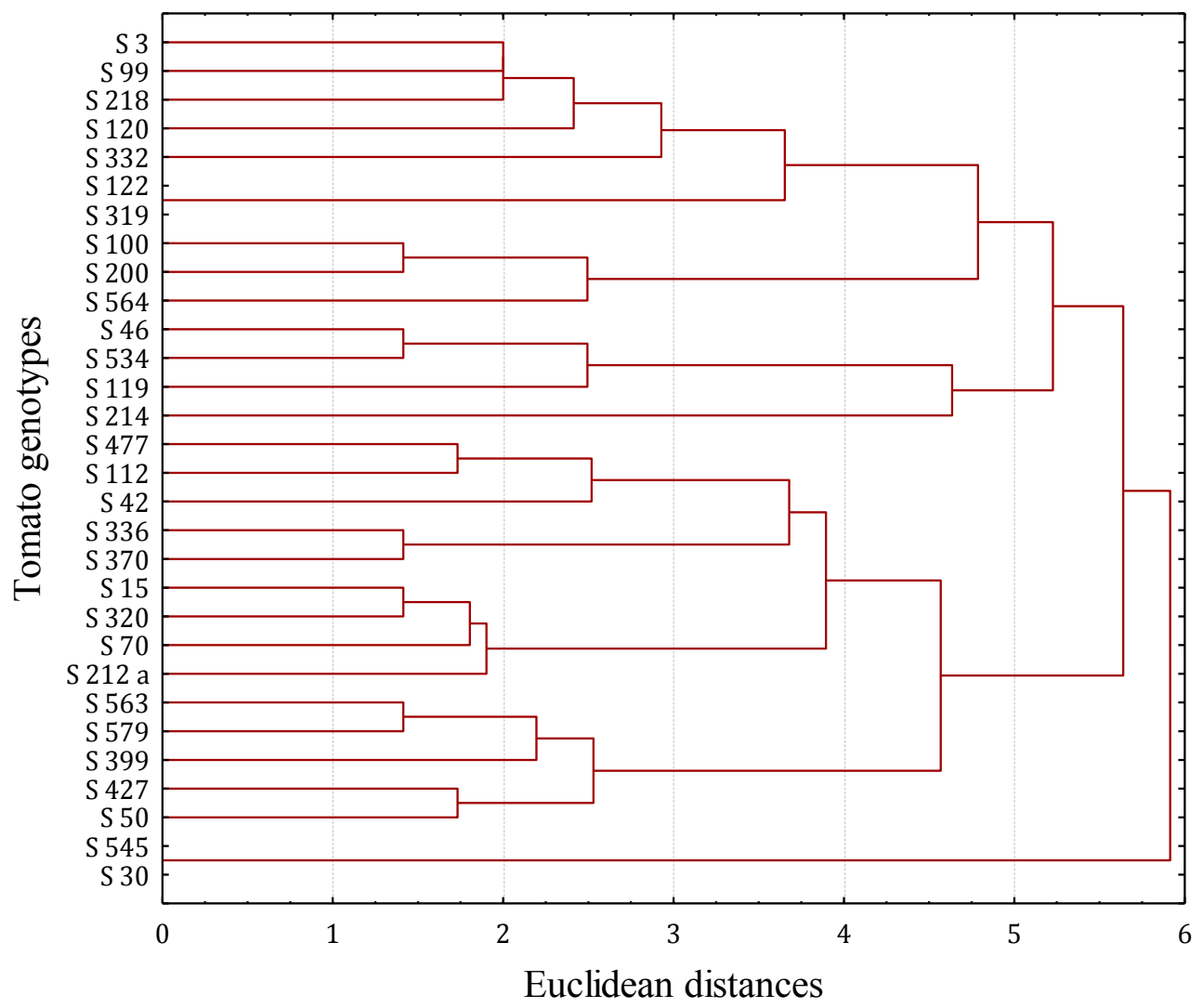

Figure 1. Dendrogram of 30 tomato genotypes based on 8 SSR markers data 


\section{References}

Alvarez, A.E., van de Wiel, C.C.M., Smulders, M.J.M., \& Vosman, B. (2001). Use of microsatellites to evaluate genetic diversity and species relationships in the genus Lycopersicon. Theoretical and Applied Genetics, 103(8), 1283-1292. doi: $10.1007 / \mathrm{s} 001220100662$

Anderson, J.A., Churchill, G.A., Autrique, J.E., Tanksley, S.D., \& Sorrells, M.E. (1993). Optimizing parental selection for genetic linkage maps. Genome, 36(1), 181-6.

Bombarely A, M. . The Sol Genomics Network (solgenomics. net): growing tomatoes using Perl. Nucleic Acids Res, 39, 11491155. Retrieved from http://solgenomics.net

Brbaklić, L., Kondić-Špika, A., Trkulja, D., \& Kobiljski, B. (2010). Asocijativna analiza između mikrosatelitskih markera i agronomski važnih svojstava pšenice. Ratar. Povrt. 47(2), 505-510.

Cadalen, T., Mörchen, M., Blassiau, C., Clabaut, A., Scheer, I., Hilbert, J.L., . . Q Quillet, M.C. (2010). Development of SSR markers and construction of a consensus genetic map for chicory (Cichorium intybus L.). Molecular Breeding, 25(4), 699722.

Chen, J., Wanga, H., Shen, H., Chai, M., Li, J., Qi, M., \& Yang, W. (2009). Genetic variation in tomato populations from four breeding programs revealed by single nucleotide polymorphism and simple sequence repeat markers. Scientia Horticulturae, 122, 6-16. doi:10.1016/j.scienta.2009.03.025

Doyle, J.J., \& Doyle, J.L. (1990). Isolation of plant DNA from fresh tissue. Focus, 12, 13-15.

El-Awady, M.A.M., El-Tarras, A.A.E., \& Hassan, M.M. (2012). Genetic diversity and DNA fingerprint study in tomato (Solanum lycopersicum L.) cultivars grown in Egypt using simple sequence repeats (SSR) markers. African Journal of Biotechnology, 11(96), 16233-16240. doi:10.5897/AJB12.2477

Food and Agriculture Organization of the United Nations. (2011). FAOSTAT database. Retrieved from http://www.faostat.fao.org

Frary, A., Xu, Y., Liu, J., Mitchell, S., Tedeschi, E., \& Tanksley, S. (2005). Development of a set of PCR-based anchor markers encompassing the tomato genome and evaluation of their usefulness for genetics and breeding experiments. Theoretical and Applied Genetics, 111(2), 291-312. doi:10.1007/s00122-0052023-7

García-Martínez, S., Andreani, L., Garcia-Gusano, M., Geuna, F., \& Ruiz, J.J. (2006). Evaluation of amplified fragment length polymorphism and simple sequence repeats for tomato germplasm fingerprinting: utility for grouping closely related traditional cultivars. Genome, 49(6), 648-656. doi:10.1139/ G06-016

He, C., Poysa, V., \& Yu, K. (2003). Development and characterization of simple sequence repeat (SSR) markers and their use in determining relationships among Lycopersicon esculentum cultivars. Theoretical and Applied Genetics, 106(2), 363-73. doi:10.1007/s00122-002-1076-0

Hu, X., Wang, H., Chen, J., \& Yang, W. (2012). Genetic diversity of Argentina tomato varieties revealed by morphological traits, Simple Sequence Repeat, and Single Nucleotide Polymorphism markers. Pakistan Journal of Botany, 44(2), 485-492.

Peterson, D.G., Price, H.J., Johnston, J.S., \& Stack, S.M. (1996). DNA content of heterochromatin and euchromatin in tomato (Lycopersicon esculentum) pachytene chromosomes. Genome, 39, 77-82.

Shah, S.M., Naveed, S.A., \& Arif, M. (2013). Genetic diversity in Basmati and non-Basmati rice varieties based on microsatellite markers. Pakistan Journal of Botany, 45(s1), 423-431.

Stich, B., Maurer, H.P., Melchinger, A.E., Frisch, M., Heckenberger, M., Voort, J.R., ... Reif, J.C. (2006). Comparison of Linkage Disequilibrium in Elite European Maize Inbred Lines using AFLP and SSR Markers. Molecular Breeding, 17(3), 217-226. doi:10.1007/s11032-005-5296-2

Trkulja, D., Kondić-Špika, A., Brbaklić, L., \& Kobiljski, B. (2011). Analiza veze marker-svojstvo za vreme klasanja i cvetanja pšenice korišćenjem pojedinačne marker regresije. Ratar. Povrt. 48(1), 113-120. doi:10.5937/ratpov1101113T

Jatoi, S.A., Fujimura, T., Yamanaka, S., Watanabe, J., \& Watanabe, K.N. (2008). Potential loss of unique genetic diversity in tomato landraces by genetic colonization of modern cultivars at a non-center of origin. Plant Breeding, 127(2), 189-196. doi:10.1111/j.1439-0523.2007.01446.x

\title{
Molekularna evaluacija genetičke varijabilnosti paradajza (Lycopersicon esculentum Mill.) mikrosatelitskim markerima
}

\author{
Svetlana Glogovac • Adam Takač • Ljiljana Brbaklić • Dragana Trkulja • Janko Červenski • \\ Jelica Gvozdanović Varga • Vukašin Popović
}

Sažetak: Paradajz (Lycopersicon esculentum Mill.) je jedna od povrtarskih vrsta najviše izučavanih na polju oplemenjivanja, genetike i genomike i jedna od 3000 iz familije Solanaceae (pomoćnice). Veličina genoma paradajza iznosi 950 Mbp, a sadrži $77 \%$ heterohromatina i 23\% euhromatina (Peterson, Price, Johnston i Stack 1996). Iako je diverzitet njegovih prirodnih staništa veoma velik, znatan deo genetičke varijabilnosti paradajza je izgubljen u procesu domestifikacije i intenzivne veštačke selekcije. Cilj ovog istraživanja je procena genetičkog diverziteta 30 genotipova paradajza iz kolekcije Instituta za ratarstvo i povrtarstvo u Novom Sadu korišćenjem 8 mikrosatelitskih markera. SSR markeri su izabrani na osnovu objavljene naučne literature i Solanaceae Genome Network baze podataka. Markeri SSR 248, TMS 9 , TMS 42 i SSR 111, kod kojih je utvrđena visoka PIC vrednost, mogu se preporučiti za buduća istraživanja. Ključne reči: genetička varijabilnost, genetika, Lycopersicon esculentum, mikrosateliti, paradajz, SSR markeri 